\title{
Spotlight on ponatinib in the treatment of chronic myeloid leukemia and Philadelphia chromosome-positive acute lymphoblastic leukemia: patient selection and perspectives [Erratum]
}

\author{
Anagnostou T, Litzow MR. Blood Lymphat Cancer. \\ 2018;8:1-9.
}

On page 2, Table 1 was incorrectly presented. Table 1 should have been:

Table I Inhibition of kinases by different TKls approved for the treatment of CML and/or ALL

\begin{tabular}{llllll}
\hline Kinase & Imatinib & Dasatinib & Nilotinib & Bosutinib & Ponatinib \\
\hline ABLI & $X$ & $X$ & $X$ & $X$ & $X$ \\
T3I5I & & $X$ & & $X$ & $X$ \\
FGFR & & $X$ & & $X$ & $X$ \\
VEGFR & & & & $X$ & $X$ \\
PDGFR & $X$ & $X$ & $X$ & $X$ & $X$ \\
KIT & $X$ & $X$ & $X$ & & $X$ \\
FLT3 & $X$ & & & $X$ & $X$ \\
SRC & & $X$ & & $X$ & $X$ \\
\hline
\end{tabular}

Note: Over $50 \%$ inhibition is indicated by $X$.

Abbreviations: $A L L$, acute lymphoblastic leukemia; $C M L$, chronic myeloid leukemia; TKIs, tyrosine kinase inhibitors; ABLI, abelson murine leukemia viral oncogene homolog I; FGFR, fibroblast growth factor receptor; VEGFR, vascular endothelial growth factor receptor; PDGFR, platelet-derived growth factor receptor; KIT, stem cell growth factor receptor; FLT3, fms-like tyrosine kinase 3; SRC, sarcoma kinase.

\section{Publish your work in this journal}

Blood and Lymphatic Cancer: Targets and Therapy is an international, peer-reviewed, open access journal focusing on blood and lymphatic cancer research, identification of therapeutic targets and the optimal use of preventative and integrated treatment interventions to achieve improved outcomes, enhanced survival and quality of life for the cancer patient. The manuscript management system is completely online and includes a very quick and fair peer-review system. Visit http://www.dovepress.com/testimonials.php to read real quotes from published authors. 